\title{
Traveler's Knowledge and Attitudes to Access Tourism Health Centre at Gunungkidul: Case Study at Indrayanti Beach
}

\author{
Noval Ali Lating ${ }^{1}$ and Liena Sofiana ${ }^{1 *}$ \\ ${ }^{1}$ Faculty of Public Health, University of Ahmad Dahlan, Yogyakarta, Indonesia \\ * Correspondence: liena.sofiana@ikm.uad.ac.id. Tel: +6285875555584 \\ Received 09 January 2020; Accepted 30 March 2020; Published 05 May 2020
}

\begin{abstract}
Background: Indrayanti beach located at Gunungkidul district, Yogyakarta. The number of tourists visited this beach has increased each year, meaning that it increases the health risks for the tourist and people involved such as infectious diseases, blisters, lost, injured by objects or marine animals, seawater irritation. However, according to the previous study, a traveler who is accessing the Tourism Health Centre is low. This research aimed to identify the relationship between knowledge and attitude of the travelers in Indrayanti Beach to the traveler's access to the Tourism Health Centre.

Method: Quantitative analytical approach with a cross-sectional study design was applied in this study. Of 106 travelers was participate in this study that was recruited through accidental sampling. A tested questionnaire contained knowledge, and attitude was asked to the Indrayanti visitor. A Chi-square test was used to analyze the result.

Results: There is a significant association between knowledge level $(p=0.027)$ and attitude $(p=0.000)$ to the willingness to access the Tourism Health Centre.

Conclusion: Knowledge and attitude are the primary aspects of the willingness to access the Tourism Health Centre.
\end{abstract}

Keywords: Knowledge, Attitude, Travelers, Usage, Tourism Health Centre

\section{INTRODUCTION}

Tourism is each tour activity supported by facilities and services provided by the public, employers, government, and local government (1). Tourism in Indonesia is part of a socialeconomic activity. Indrayanti beach is one of the famous tourist destinations in the Yogyakarta Special Region, both for the domestic and foreign visitors. This beach located in Gunungkidul district, in the east of Yogyakarta. According to the Tourism Statistics from Yogyakarta Tourism Office, the number of visitors to Gunungkidul is increasing since 2016 with 1.9 million visits or equal with 160,000 visitors per month, and it continues the year after. In 2017, recorded 2,2 million visitors or 180,000 people per month (2),(3).

Today, the development of tourist sectors prioritizes the comfort and safety of the visitors. Along with the increasing number of tourists, it is followed by a rising of health risks, although it depends on the physical condition of the tourists (4). Hence, attention to facilities, in particular, the health facilities or called Tourism Health Centre is needed. 


\section{Epidemiology and Society Health Review $\mid \boldsymbol{E S H R}$}

Information about this facility is essential to guide the visitor on seeking help when they have a problem in a particular resort.

Several factors could be influencing a person's behavior on accessing service in the tourism health center. According to the Health Behavior Model of Health Services Utilization, there are three factors that influence the utilization of health services: predisposing and enabling need (5). Predisposing is a factor that facilitates one's interaction, such as knowledge, attitudes, traditions and beliefs, value systems, educational levels, socioeconomic and enabling is a factor that allows behavior including the availability of infrastructure or health facilities for the community. Previous studies stated, there is a relationship between knowledge and attitudes of domestic and foreign tourists with tourism health center utilization (6). In addition, it was known that there was a relationship between knowledge and utilization of health services also the association between level of emergency travel knowledge with the utilization of tourism health center (7),(8). Considering the importance of the topic, this research aimed to analyze the association between knowledge and attitudes of Indrayanti visitor to the usage of Indrayanti tourism health center, which is provided by the district government of Gunungkidul.

\section{METHODS}

This study carried out at Indrayanti beach, Gunungkidul, by using an observational study with a cross-sectional approach (9). Accidental sampling was applied to recruit the respondent. The samples were travelers who were in Indrayanti Beach with minimum hold senior high school educations. The sample size was 106 respondents based on a sample calculation with an unknown population. The independent variable in this study is the knowledge and traveler attitudes, while the dependent variable is the utilization of Gunungkidul Tourism Health Centre. We used a questionnaire that had previously been tested for validity and reliability - respondents filled in the questionnaires by themselves. Data was administered with cleaning, editing, coding, and entering the software for the Chisquare test.

\section{RESULTS}

Respondent characteristic is presented by gender, age, education, and occupation (Table 1 ). The majority of the respondents are female $(n=67 ; 63.2 \%)$. Eighty respondents or $(75.5 \%)$ of respondents come from outside of Gunungkidul. As to education, more than half of the respondents belong to the age group of $17-25$ years old $(n=54 ; 50.9 \%$. More than $40 \%$ of respondents are students $(n=47 ; 44.3 \%)$. Most of the respondent $(n=65,61.3 \%)$ hold university educations.

Chi-square test between the level of knowledge to the utilization of Gunungkidul Tourism Health Centre obtains $p$-value $=0.027$ with $\mathrm{PR}=1.237(95 \% \mathrm{Cl}=1.027-1.490)$, meaning that the significant associated. Visitors who have good knowledge have 1.237 times as likely to use the Tourism Health Centre compared to people who have insufficient knowledge. While for attitude, we found $p=0.000$ with $P R=1.549(95 \% \mathrm{Cl}=1.206-1.989)$, meaning that the people who have a positive attitude, they have 1.5949 times as likely to use the Tourism Health Centre compared to people with negative attitudes (Table 2). 


\section{Epidemiology and Society Health Review $\mid \boldsymbol{E S H R}$}

Table 1. Demographic Characteristics of the Respondents

\begin{tabular}{lcc}
\hline \multicolumn{1}{c}{ Characteristics } & Frequency & Percentage (\%) \\
\hline $\begin{array}{l}\text { Gender } \\
\quad \text { Male }\end{array}$ & 39 & 36.8 \\
$\quad$ Female & 67 & 63.2 \\
Age & & \\
$17-25$ & 54 & 50.9 \\
$26-35$ & 33 & 31.1 \\
$\quad 36-45$ & 19 & 17.9 \\
Address & & \\
$\quad$ Gunungkidul & 26 & 24.5 \\
$\quad$ Outside of Gunungkidul & 80 & 75.5 \\
Education & & \\
$\quad$ High School & 41 & 38.7 \\
$\quad$ University & 65 & 61.3 \\
Occupation & & \\
$\quad$ Government employees & 13 & 12.3 \\
$\quad \begin{array}{l}\text { Private employees } \\
\quad \text { Entrepreneur }\end{array} \quad 21$ & 19.8 \\
$\quad$ Labour & 11 & 10.4 \\
$\quad$ Student & 14 & 13.2 \\
\hline Total & 47 & 44.3 \\
\hline
\end{tabular}

Source: Primary Data, 2019

Table 2. Correlation between Level of Knowledge, Attitudes and the Utilization of Tourism Health Centre

\begin{tabular}{|c|c|c|c|c|c|c|}
\hline \multirow{3}{*}{ Variables } & \multicolumn{4}{|c|}{$\begin{array}{c}\text { Utilization of Tourism } \\
\text { Health Centre }\end{array}$} & \multirow{3}{*}{$\begin{array}{c}\text { PR } \\
(95 \% \mathrm{Cl})\end{array}$} & \multirow{3}{*}{ P-value } \\
\hline & \multicolumn{2}{|c|}{ Yes } & \multicolumn{2}{|c|}{ No } & & \\
\hline & $\mathrm{n}$ & $\%$ & $\mathrm{n}$ & $\%$ & & \\
\hline \multicolumn{7}{|l|}{ Knowledge } \\
\hline High & 43 & 50.6 & 5 & 23.8 & 1.237 & 0.027 \\
\hline Low & 42 & 49.4 & 16 & 76.2 & $(1.027-1.490)$ & \\
\hline \multicolumn{7}{|l|}{ Attitude } \\
\hline Positive & 59 & 69.4 & 4 & 19 & 1.549 & 0.000 \\
\hline Negative & 26 & 30.6 & 17 & 81 & $(1.206-1.989)$ & \\
\hline
\end{tabular}

\section{DISCUSSIONS}

The level of people's knowledge and behavior is influenced by the level of education. In this study, most of the respondents hold university education (61.3\%). Levels of education is an external factor that influences a person's knowledge level. Travelers who have high education will have a good knowledge level (10). Low levels of education are more likely to not access health services because of the lack of understanding about the benefits of health services when conditions are emergency (11). These results are in line with previous research stated there is a relationship between community knowledge and health care utilization (PHC) (12). A person's knowledge is related to education and age; in this research, several respondents aged between 17-25 years, which is a period of taking education. The age of someone may affect the mindset of information acceptance (10). 


\section{Epidemiology and Society Health Review $\mid \boldsymbol{E S H R}$}

Our results are consistent with previous studies that said there are relationships between knowledge and utilization of health services (7),(13). The results of this study were consistent with the theory of behavior model of health services utilization, that knowledge is one of the predisposing factors that affect a person in the use of health services (5). People who have not used health services at tourist sites can be caused by a lack of information regarding the existence of these health service locations. Simply and accurate information are needed to inform the visitor about the presence of these health services. The information form can be various media, both print, and electronic media, that provide health information and health services (14).

The attitude is the driving force to perform or not a particular behavior, and attitude is more to an individual's awareness process. A good attitude influences the actions in the utilization of the Tourism Health Centre. Traveler attitude in this study belongs to the category quite well; this is good for the tourist administrators to increase the media to inform the existence of the Tourism Health Centre (15). Knowledge relates to a person's attitude in the utilization of health services after people know the importance of health services; a good attitude will be formed. Such as, people agreeing to use health services or even giving advice to others to be able to use health services when needed (15).

The travel environment also affects the visitor's attitude. Visitors generally susceptible to microorganisms because they visit a new area. Environmental hygiene is an essential aspect of visitors. The cleanliness tourist spot is the most important thing for the visitor because it affects their health. It corresponds to the theory that all the conditions surrounding people is affecting the development and attitudes. Through mutual interaction will affect the practice of someone on hygiene sanitation (16).

Having a high level of knowledge and a positive attitude may indicate the level of compliance with the use of the Tourism Health Centre is excellent. Thus, tourists expected to be able to recognize potential hazards in the tourist destination and able to understand what they should do to protect the health and minimize the risk of accidents when traveling especially coastal tourism.

The satisfaction of foreign tourists to visit tourist sites is also influenced by the quality of services provided, such as the presence of health services at tourist sites. The better quality of medical services leads the higher tourist satisfaction (17). The presence of clinics or health services, search and rescue teams (SAR), and proper infrastructure is influencing visitor satisfaction (18)-(20).

\section{CONCLUSIONS}

Based on the results of this study concluded that there is a relationship between the level of knowledge and attitudes to the use of the Tourism Health Centre at Indrayanti beach, Gunungkidul.

\section{Authors Contribution}

NAL contributed to the data collection and analysis of the data. LS contributed to the data analysis and manuscript preparations.

\section{Funding}




\section{Epidemiology and Society Health Review $\mid \boldsymbol{E S H R}$}

This research does not receive external funding.

\section{Conflict of interest}

There is no conflict of interest.

\section{REFERENCES}

1. Undang-Undang RI No 10 Tahun 2009 tentang Kepariwisataan. 2009.

2. Dinas Pariwisata DIY. Statistik Kepariwisataan 2015. Yogyakarta: Dinas Pariwisata DIY; 2016.

3. Dinas Pariwisata DIY. Statistik Kepariwisataan 2017. Yogyakarta: Dinas Pariwisata DIY; 2018.

4. Ismayanti. Pengantar Pariwisata. Jakarta: Grasindo; 2011.

5. F M. Memperkenalkan Sosiologi Kesehatan. Jakarta: Universitas Indonesia Press; 2014.

6. Nurjanatun D. Hubungan Tingkat Pengetahuan dan Sikap Wisatawan Terhadap Pemanfaatan Klinik Swasta. Universitas Diponegoro; 2012.

7. Singal HI V, Kandou GD, Rumayar AA. Hubungan Antara Pengetahuan, Sikap dan Pendapatan Dengan Pemanfaatan Puskesmas Oleh Masyarakat Desa Kima Bajo Kecamatan Wori. KESMAS. 2018;7(5).

8. Syaifudin A, Sapuwan. Hubungan Tingkat Pengetahuan Tentang Kegawatdaruratan Wisata Dengan Pemanfaatan Klinik Di Area Water Blaster Semarang. Semin Nas dan Call Pap. 2014;24:132-49.

9. Notoatmodjo S. Metode Penelitian Kesehatan. Jakarta: Rineka Cipta; 2016.

10. Budiman dan Riyanto. Kapita Selekta Kuesioner Pengetahuan dan Sikap Dalam Penelitian Kesehatan. Jakarta: Salemba Medika; 2013.

11. Napirah MR, Rahman A, Tony A. Faktor-Faktor Yang Berhubungan Dengan Pemanfaatan Pelayanan Kesehatan Di Wilayah Kerja Puskesmas Tambarana Kecamatan Poso Pesisir Utara Kabupaten Poso. J Pengemb Kota. 2016;4(1):29-39.

12. Junaidi H, Yunita A. Staf Pengajar Program Studi S1 Keperawatan STIKes Yarsi Sumbar Bukittinggi Mahasiswa Program Studi S1 Keperawatan STIKes Yarsi Sumbar Bukittinggi. 2012;

13. Nurjanatun D, Pramono D. Hubungan Tingkat Pengetahuan dan Sikap Wisatawan Terhadap Pemanfaatan Klinik Wisata. Media Med Muda. 2012;

14. Fatimah S, Indrawati F. Faktor Pemanfaatan Pelayanan Kesehatan di Puskesmas. Higeia J Public Heal Res Dev. 2019;1(3):84-94.

15. Pratiwi A, Raharjo BB. Pemanfaatan Pusat Pelayanan Kesehatan (Puslakes) Universitas Negeri Semarang. Higeia J Public Heal Res Dev. 2017;1(4):49-60.

16. Anom P, Baiqurul M, Sunarta N, Adikampana M. Pariwisata Berkelanjutan dalam Pusaran Krisis Global. Bali: Udayana University Press; 2010.

17. Nugraha YE, Paturusi SA, Wijaya N. Kualitas Layanan Wisata Medis Yang Mempengaruhi Kepuasan dan Loyalitas Wisatawan Mancanegara Di Bali. JUMPA. 2019;5(2):348-70.

18. Suharmiyati, Handayani L, Maryani H. Analisis Diskriptif Perbandingan Kelayakan Puskesmas Wisata Pantai dan Puskesmas Non-Wisata Pantai di Provinsi Bali (Analisis lanjut Rifaskes 2011). Bul Penelit Sist Kesehat. 2014;17(3):267-74.

19. Ristiani IY. Pengaruh Sarana Prasarana Dan Kualitas Pelayanan Terhadap Kepuasan Pasien. Coopetition. 2017; VII(2):155-66.

20. Wijono D. Tingkat Kepuasan Pengunjung Obyek Wisata Pantai Kuwaru Sanden Bantul Yogyakarta. J Maksipreneur Manajemen, Koperasi, dan Entrep. 2014;4(1):22-35. 
Epidemiology and Society Health Review $\mid \boldsymbol{E S H R}$ 